\title{
POSTAWA CHRZEŚCIJAN AFRYKI RZYMSKIEJ PODCZAS ARESZTOWANIA I UWIEZIENIA*
}

Plerwszy okres rozwoju chrześcijanistwa zrodzil wiele problemów, które wakiejó mierze są aktualne do dziś. Szczególnie znaczace w tym względzie aq czasy przé́ladowanta chrześc1jan, ukazuJace cała moo rodzacego sle Kościoła Chrystusomego. Wiele spraw tego okresu zostało juz nyśwletlonych 1 wielokroc przedyskutowanyoh. Wydaje sie jednak, ze nlezbyt wystarczajaco ukazane sa te aspekty prześladowan, które dotyoza postaw chrześc1jan - męczenników przed sadaml rzymsk1m1.

Procesy wytaczane chrześljanom 1 cała lch procedura prawna dostarczały wiele okazj1 do dawanta éwiadectia ryznawanoj wierze. Cazy bowlem proces prześladowanczy obejmowaz zasadniczo piéc etapów: aresztowanie, pobyt mięzieniu, przosłuchanie, wydante 1 wykonanie wyroku. W niniejszym artykule zajmlemy sle omówientem postaw męczenntków jedynie podczas dwóch plerwszych etapó postępowania prześladowczego. Móm1qo o pobycie więzientu, będziemy niek1edy zaczyl1 dwa róne chronologioznie okresy: pobyt wiezientu przed przesłuchaniem 1 pobyt wiezientu po wydanym juz wyroku w oczekiwantu na śmierć. Dołączymy ponadto szereg uwag, niekoniecznie zwiazanych z wý́wletlanym problemem, ułatwlajacych jednak lokture starozytnych źródez martyrlologicznyoh. Całość omawianego zagadnienia ujmiemy dla wiekszej przejrzystośc1 w cztery paragrafy. Najpierw przypomnimy rzymskie dekrety prześladowczo czyll podstawy prawne aresztowania 1 cazej procodury sadowej, nastepnie przedstawimy okolicznosel aresztorania, potem warunki wiezienne, a wreszcie to,

$x$ Jest to Iragment pracy maglsterskiej pt. "Postawa chrześojjanmęczennikow przed sqdami pogańskimi Afryoe Rzymskiej, Lublin 1982 /mps BKUL/ plsanej pod kierunkiem ks.doc.dr.hab. Jana Srutwy przy Katedrze Higtoril Kosoloza Starozytnego KUL. 
co nas najbardztej interesuje: przejaly zycla religifnego podczas tych etapón prześladowanta.

1. Prawodawstwo rzymskie a prześladowant chrześcijante

Czasy prześladowaí chrześcijan mozna najogólniej podzielić na dwa okresy: plerwszy - trwający do końca II w., drugl - obejmujacy wiek III 1 pocz. IV do mydania tzw. Edyktu Mediolańskiego 313 roku. Cecha charakterystyczna dwu pierwszych wieków był brak Jakichkolwiek specjalnych praw zabraniajacych wyznawania religil Chryatusa ${ }^{1}$. Prześladowań dokonywano na podstawie ogólnego prawa karnego, a wzczeg6́lnośc1: za śriętokradztwo/sacrileg1um/, obraze majestatu /crimen laesae malestatis/2, uprawianie zbrodniczej magil, oraz za niedozwolone zgromadzenta.

Szczegółowy zaś sposób postępowania urzęników państwowych myznaczały reskrypty cesarskie. Plerwszym zich było zarzadzenie cesarza Trajana $/ 98-117 / z 112 \mathrm{r}$. skierowano do namiestn1ka B1tynil 1 Pontu Pliniusza Młodszego, ze nie nalezy myszukiwać anl urzęomo ácigać chrześcijan, ale karać tylko tych, którzy będac prawnie oskarzent trwaja przy wyznawantu nowej wiary. Tych zaś, którzy zaprzecza, ze sa chrześcijanami 1 dowloda tego przez oddante czci bogom rzymskim, nalezy uznad́ za niewinnych ${ }^{3}$. Cesarz Hadrian /117-138/,

1 Th.Manmsen, Der Religionsfrevel nach romischen Recht, "Historische Zeitschrift" 54/1890/389-429; Por. J.Moreau, La Persécution du christian1sme dans l'emplre romain, Par1s 1956, 67: "Wcześntejsze prawo wyklucza sam sporadyczny 1 nieregularny charakter prześladowaí, a takze wahania urzędników, ktorych bez wątpienia nie normuje żaden określony tekst prawny. Skynne "Institutum Neronianum" /Tertulilanus, Ad nationes 1,7/. stanow1 nie prawo, leoz po prostu zwyczaj zapoczatkowany przez Nerona".

2 Sacrileglum 1 crimen laesae malestatis uwazano za zdrade główna 1 nawet $w$ stosunku do obywateli rzymskich wolno było stosowaó za nie takie kary jak: spalenie, ukrzyzowante, rozszarpante przez dzikie zwierzęta 1 tp. Dopuszczalne tez było stosowanie tortur.

3 Plintus, Epistolae X, 96: "Conquirendi non sunt; s1 deferantur ot arguantur, puniendi sunt, ita tamen, ut qui negaverit se christianum esse idque reipsa manifestum fecerit, id est supl1cando dis nostris, quamvis suspectus in praeteritum, veniam ex poenitentia impetret". 
w odpowiedzl danej namiegtnikowi dzjl Minucjuszowi Fundanusow1 v 125 r., uśc1ślił jeszcze reskrypt swego poprzednika mymagajac, by donosy na chrześcijan były Imienne 1 poparte dowodami 4 . Zasade Trajana ukaranta opornych, a zwalniania apostatow, powtórzyz póznlej cesarz Marek Auroliusz /161-180/ reskrypclo sklerowanym do legata prowincj1 11 orskiej ${ }^{5}$.

Sytuacja prawna uległa zmianie wieku III, gdy zaczeły sie ukazywad ogólnopástwowe edykty prześladowcze. 0 1le poprzednio przésladowania chrześcijan miały charakter lokalny 1 często zalezaky od Intojatywy poszczególnych urz̧̨aników, to teraz wszyscy onl mieli obow1azek wyszuk Iwanta lch 1 zmuszania do apostazj1. Trajanowe "conquirendi non sunt" zastapiono "conquirendl sunt et puntend1". Tego rodzaju prześladowania rozpoczezy sie cesarz Septymlusz Sewer /193-211/, zanlepokojony szybkim rozszerzan1em s1a chrześcijaństwa, zabron1z przyjmowania nowej relig11. Zarządzenie to nie obejmowało tych, którzy byll juz chrześcifanam1, ale sklerowane było przede wszystkim przeciw krzewiclelom nowej relig11 oraz przeciw katechumenom 1 nowo ochrzczonym ${ }^{6}$. Edykt jednak stosowano dość łagodnie 1 krótko. Woplero cesarz Necjusz /249-251/ zapoczątkowal krwawe prześladowania w całym Imperium. Uznał, ze zaprowadzente ladu 1 porzadku podupadajzcym państwie osiagnie przez powrót do starej relig11, która przoszłośc1 zapewniła Rzymow1 wielkość. Dlatego ok. $250 \mathrm{r}$. wydaz edykt, w którym nakazał, aby wszyscy obywatele złozyll oflare błagalną z prośba o pomyślność dla państwa. Edykt nie odnosiz slę nyłącznie do chrześcijan, a le w nich uderzaz najbardziej, a szczególnie w duchownych ${ }^{7}$. To bowlem,

4 Just1nus, Apologia I 68, PG 6,432, POK 4,79/List Iladriana do Fundanusa/ "Jeśli mleszkajoy prowinoji mog7 podtrzymać uzasadnione oskarzenle przeciwko chrześoljanom, tak ze sprawę mozna wytoozyó przed trybunazem, niechzesz tylko tak postepuja, a niech $81 \theta$ nie uolekaja do gołosłownych ząaŕ 1 krzyk6w. Jest bow 1 em - wiele leplej, ze ty rozstrzygniesz, czy skarga jest uzasadniona. Jeśl1 więo oskarzyciel udowodn1, ze się dopuśc1l1 jak1egoś bezprawia, wydaj wyrok stosownie do wielkośc1 przestepstwa". Por. Eusobius, Historia occlosiastioa/HF/ IV $9, \operatorname{SCh} 31,172, \operatorname{POK} 3,155$ 156.

5 Por. Euseb1us, HE V, 1 PG 20,407 nn, POK 3, $193 \mathrm{nn}$.

6 Trudno natomiast ustal16, ozy zarzadzenie to obejmowako zakaz ohrześo1janskiego wychowan1a dz1001 przez rodzió́w-ohrześcijan.

$7 S_{w}$. Cyprian nazywa Deojusza "tyrannus Infestus sacerdotibus" - 
co dla poganina było zwykłym gestem, wykonanym jako czysta formalnoś bez głębszego znaczenia, dla chrzescijanina było znakiem apostazj1 1 zaparcia sie wiary. Za odinówiente złozenia oflary edykt przenidywaz konilskate majłtku, mygnante, praoe w kopalni, tortury, a nawet śmierć. Nienntej krrawe przésladowanie wybuchło w sledem lat póziniej, za cesarza ïaleriana /253-260/, który wydaz dwa formalne edykty prześladowcze. Plerwszy, z 257 r.., nakazywał duchownym chxześcijariskim pod kara wygnania składanie ofiar bóstwom rzymskim oraz zabranial pod karł śmlerc1 พstępu na cmentarze 1 uczestnictia w zgromadzentach liturglcznych. Drug1 zaś, wydany w roku następnym, zaostrzał jeszcze bardzjej postanovienia plerwszego: duchownl, którzy uchylali sia od złozenla ofiary, miell być natychmiast traconl. Ten sam los miał spotkać chrześcijan śrleokloh z klasy senatorsklej 1 rycerskioj. Prześladowanto to jednak ustało wraz ze śmierola cesarza.

ostatnie wielkie przésladowante rozpoczeło sle za panowanla Djoklecjana /284-305/, który poczatkowo sprzyjał nawet chrześcijanom, alo zmtcniz swoja postawe pod wpływem Galeriusza. Wstepem do prześladowanta było usuntęc1e chrześc1jańskich zołnierzy z armil nie chcacych oddać bosiciej czcl cesarzori. Plerwszy edykt Dioklecjana, dotyczicy wszystkich chrzescijan, wyszedz w lutym 303 r. Nakazywat on burzento budowl1 sakralnych 1 niszczente wszelkich przedmiotów zwiłzanych z kultem oraz zakazywaz zebrań liturgicznych. Wszystrich wyznawc6́ Chrystusa pozbawiano praw obywatelokich, tych zaś, ktúrzy byl1 na słuzbie cesarskiej uwięziono. Choclaz odykt nie przewldywał kary śmlerc1, jednak zdarzało slę, zo ponosill ja niorzadko ci, którzy nte chcieli wydá́ ksiag święyoh. Drugi z kole1 edykt Dioklecjana ukazał si $w$ kilka tygodni po plerwszym. Nakazywal on uwleziente duchownyoh, ale nie przewidywał kary śmierci. Bdykt trzeci oblecywał wolnosé tym chrześc1janor, którzy wyrzekna się wyznawanej wlary, a opornym groz1l torturaml. I wreszcle edykt ozwarty, wydany pod nieobecność Dioklecjana wlosnz 304 roku przez Galeriusza, nakazywał, podobnie jak za Decjusza, składanio ofiar przed

Por. Epistola 55,$9 ;$ PSP 1,147 . 
bóstwaml religil rzymsklej wszystkim mieszkanicom cesarstwa, a dla oponentów przeridywaz kare śmlercl lub zesłania na cięźkie roboty 7 kopalniech. Wprowadzanie cesarskich zarziłdzé́ w zycle zależazo ostatecznie od gorl1wośc1 poszczególnych urzędników. Stąd tez 1ntensywność prześladorań jak 1 sam przebleg procesów sądowych oraz obchodzente się z oskarzonymi bymały odmienne w róznych częściach cosarstra.

\section{Okolicznośc1 aresztowan1a chrześcijan}

Aresztowania chrześc1jan dokonywall przedstawiclele waadzy centralnej albo urzednicy municypaln1. Do piernezych nalezel1 zarządcy poszczególnyoh prowincjl afrykańskich, a wįc prokonsul * Afryce Prokonsularnej, legat cesarsk1 w Numldil 1 prokuratorzy/nazywant tez praefecti lub presides/. Posługiwall sie przy tym polioja, a nlerzadko 1 wojsklem. I tak św. Cypriana aresztowali z rozkazu prokonsula Galeriusza Maksyma diaj wyzsi oflcorowie/principes/: przydzielony do słuzby prokonsula strator oraz pelnifcy te same obowiazk1 ${ }^{8}$ equistrator. W Numidil natomiast, gdzie stacjonowar III legion, chrześcijan myszukiwali zołnierze, 1 to nie pojedynczo, ale cala centur $a^{9}$. Innym razem zwaszcza za prześlacorania cesarza Dioklecjana aktu uwięzienta dokonywall urzędnicy municypalni. Tak na przykład mlejscowoścl ' $\mathrm{T}$ hlbiuka, kurator tego mlasta lagnilianus, kazal soble przyprowadzić najplerw starszych z ludu, a wéród nich prezbitera Apra 1 dwóch lektorów Cyryla 1 Witalisa, potem zaś 1 b18kupa Feliksa, gdy powrólł z Kartaginy. Aktu aresztowania dokonala policja /oficium/ $/^{10}$. W Abitynie natomiast prezbitera Saturnina, razem z wiernyml zgromadzonyml na oelebrowantu Eucharyst11, aregztowall miejscowl urzędnioy /maglotratus coloniae/ wspólnie a pol1-

8 Aota S.Cyprjani 2,5, ed. D.Rulz Bueno, Actas de los martires, Madrid $1974^{3}, 758$ /To wydanie akt męceńskich stanowié będzie podstawe źródłowa naszyoh dociekan, cytowang: Bueno/; Vita $S$. Cyprian1 15, Bueno 744. Termin "strator" lub "stator" oznacza oftcera dyzurnego ordynansa. Zas equistrator lub equistator znaczy to samo, tylko przy dowódcy oddzlału, konnego.

9 Passio Marlant et Jacob1 214 , Bueno $825 \mathrm{nn}$.

10 Passio S. Fellols 1-3, Bueno $961 \mathrm{nn}$. 
cja ${ }^{11}$. W Cyroie wreszole myszukiwaniem ksiag Plama śn. 1 paramentów 1iturgioznych zajmował s1e kurator tego miasta, kapłan pogańsk1/Plamen perpetuus/, Minat1us Foliks ${ }^{12}$.

Interesuje nas postawiony na wstepie problem zachowania ofe chrześc1jan $w$ chwil1 aresztowania. Otóz na podetaw1e skapyoh 1nformacj1 źrółowych mozna zauwazyé, zo wyznawoy Chrystusa nie przostrasyli sie ani rzymsklego prawa, ani mozliwosel męczeństwa. $S_{w}$. Cyprian ukrywał ale wprawdzie podozas prześladowania Deojusza, ale za Waleriana juz nie opuśc1 gmojej owozarni. Nawet jednak wtedy, gdy sie ukrymal nie czyniz tego - jak p1sze jego blograf Poncjues Diakon - ze strachu, ale dla utwierdzenia bracl we wierze 13 dia dobra Kó́cloła ${ }^{14}$. Podczas przélladowania Waleriana pozostal jako biakup na swolm miejscu razem z wiernymi. Mimo, 12 pierwszy edykt cesarski skazywał duchownych odwawlajacyoh składanta of 1 ary na wygnanie, drugi juz na karé ́́mierol. Cyprian nie podporzadkowaz sie tadnemu. Zostal najpierm nywieziony na mygnanie do miasta Kurubis ${ }^{15}$, skąd podczas druglego edyktu Waleriana powrócil do Kartaginy. Trwajao na swym urzędzie dzięki widzeniu wiedziaz, te zostanio aresztowany 1 skazany na émier ${ }^{16}$. Mimo to spokojnie oozekiwaz w owoloh ogrodach na przybycie strazy prokonsula. Aresztowany przez dwóch oficerón udaz sie z nimi - Jak opisuje Poncjusz Diakon - "z duohem podniesionym 1 wyniosłyin, z pogarda na obliczu, a męstwem seroun ${ }^{17}$.

11 Passio SS.Saturnini Dativi 2, Bueno 972 nn.

12 Gesta apud Zenophilum I 18-32 CSEL 26, 186.

13 Vita Cypriani 7 , Bueno 733, POK 19,628 "Któzby upadzyoh uozyz pokuty, heretyków prawdy, sohizmatykow jedności? /.../ od kogos

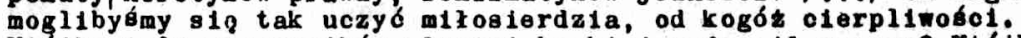
Któzby tylu męozenników słowami boskiej podnosil wymowy? Któbby wreszole tylu wyznawców, tyle głów po raz wtóry na męozérstwo zaznaczonych, a na przykład tegot mp̧ozeratwa przy tyolu pozoatawionych, traby niebieskiej pobudka zapalaz".

14 Tamze, 8, Bueno 735, POK 19,63: "Został zachowany mąz - opróoz Innych dárów - wyrobionego ducha, który /.../ prowadziz Kósoló "óród odmętów".

15 Tamze, 11, Bueno 139, POK 19,67: "Brudne, nieprzyjemne, nie posiadajace zdrowej wody, niepociagajace, oddalone od wybreza; rozległe, skaliste wzgórze zalesione, wóród niegó́cinnyoh wąrót. pustyni, jest chyba tylko dla ptakón' dostepnen.

16 Tawze 12-13 Bueno 739 nn. Por. Ep1stola 80,1, PL 4,430, w któryn odwozany juz $z$ wygnania, informowal biskupa Sukoesa o drugin edykoie Waleriana 10 tym, ozego moga spodziewá sie ohrseícija-
nle. 
Chrześcijante z Abityny nie zwazali także na edykt Dioklecjana zabrantający gromadzenia się na nabożeństrach, ale zbierali sie w domu Oktawiusza Feliksa w $11 \mathrm{czb}$ le około 50 osób dla sprawowania Eucharyst11. Schwytan1 1 prowadzeni na rynek/forum/szl1 radośni /alacres/. C cozo pochodu otwieral senator Dativus w bialef todze, za nim szedł prezbiter Saturninus z czwórką swolch dzleci 1 reszta wyznawców /agmen Dominicum/. Oplsuje to autor "Pass1o S.S.Saturnini, Dativi" uzywajac słownictira biblijnego ${ }^{18}$ z listu św. Pawla do Elezjan ${ }^{19}$. Ta manilestacja wasnej wiary 1 nadzie1, wobec otaczajacych braci dla podtrzymania $1 \mathrm{ch}$ na duchu, jest charakterystyczna dla większoścl męczenntków, niemal na wszystkich etapach procedury sądowej.

Pojmanych chrześcijan nlekledy natychmiast poddawano przesłuchantom, częścłej jedrak wtrącano lch do wį̧zienta, gdzle pozostawal 1 do rozprawy 1 ostatecznego wyroku. Zdarzało się tez, ze jeszcze przed osadzenıem w wiezientu oskarżonych przetrzymywano przez jakı́s czas pod nadzorem zołnierzy czy urząuników państwowych ${ }^{20}$. Spotykamy sie z tym oplsie męczeństwa Swiętych Perpetui 1 Felicyty. Sw. Perpetua nykształcona patrycjuszka w swoim pamigtniku, prowadzonym niemal do momentu egzekucji, opisała, co zasz ło między jej aresztoraniem a uriezzieniem. Swoje oporiadanie zaczyna od słów: "Gdy byliśmy jeszcze z naszyml prześladorcam1", a koúczy zdaniem: "Po paru dniach zamknięto nas w więzieniu"21. M1ędzy tymi faktaml upłynęło więc przynajmniej kilka dnı, które męczennicy spędzili w nieokreślonym blizej aroszcie, chyba jednak w niezbyt cigzkim

17 Tamze, 15, Bueno $744 \mathrm{n}$, POK 19,71.

18 Cp 3, Bueno $974 / t ł u m$. Fłasne/: "Jaśniał z nich blask niebiesklej zbrol: tarcza riary, pancerz sprairiedliwości, cnełm zbawienta 1 miecz obosieczny, to jest słowo Boze. Niezwycięzeni w swym chwalebnym wyposazeniu dawali braciom nadzieje przyszłe-
go zwyciestiva".

19 Ef 6,14,16-17.

20 Por. Dzieje Apostolskie 281 16: "Gjyśmy weszli do $\mathrm{R}_{z y}$ m, Pawhowi pozwolono mieszkać prywatnie razem z zolnterzem, który go p1lnowal". Bedaco w tak1m doinowym areszcie laweł aogl spotykać
sie z braćmi 1 nauczać. 21 Passio SS. Perpotuae et Feliaitatis 3 , Bueno 421, tłum. A.Doma-
nlewska, R 2-3/1950/51/388. 
skoro zatrzymanl katechument mogli przyją chrzest. Takze b́w. Cyprian prżebyivał po zatrzymaniu najplerw w domu dowódcy przy prokonsulu, gdzle obchodzono sle z nim zagodnie, skoro wielu bracl mogło go odíledzać. Na zemnatrz przez cały czas czekaz tzum ludzl clekawych wydarzeri. Naleźy podkreślić, ze nawet wówczas pamiętaz on o swolch wiernych: "Polectl pllnowac dzlewczlł, poniewaz wszystkie pozostawały na wsi przed bramz domu donódcy ${ }^{22}$.

Nie zawsze jednals z zatrzymanymi chrześcijanaml obchodzono sie tak lagodnie jaik z Perpetua czy Cyprianem. Czasem od razu straszono lch śmierci lub torturami. Tak na przykład Montanus 1 Lucjusz schwytani 1 osadzent $z$ towarzyszami w areszcie/In custodia/, dowiedzieli sie od strzegacych lch zołnierzy, ze namiestnik zamierza wszystkich pojmanych spalić zywcem, od czego jednak cudownie zostal1 uratowan1 ${ }^{23}$. Męczenn1ków zaś z Ab1tyny gnębiono w ten sposób, ze tuz przed przesłuchanlem mlano wobec nioh pal16́ "Plsma Pańskie" /Scripturae dominicae/, od czego rowniez zostall cudownte uchronteni 1 postawienl bezpośrednio przed prokonsulem Anulinusem $w$ Kaxtaglnie ${ }^{24}$. $\mathrm{z} \mathrm{k1lku}$ więc oplsanych wypadków aresztowania wynlka, zo chrzescijanie w momele zatrzymania nie popadald w pantke lub dopresje, ale zachowywali sie na oół spokojnio pełnl ufnośc, zo wszystko co 1 ch spotyka, pochodzi od Boga.

\section{Warunki "ięzienne}

Po aresztowaniu chrześc1janie albo bezpośrednio byli proiradzeni na przesłuchanie, albo przez jakiś okres przebywali w wiezleniu. Zawse jednak, poza nielicznymi wyjitkaml, czas od wydania wyroku do egzekuojt skazanoy spędzall wigzlentach.

W rzymskim prawie karnym zasadniczo nie 1stniała kara wiezienla. Istnial tylko tzw. areszt prewencyjny dla porstrzymania ludzi od wystepku, a nio dla karanla za popeznione przestepstwo /ad

22 Passio S.Cypriani 2, Bueno 758, POK 19, 78, Vita Cypriani 15, Bueno 744, POK 19,71.

23 Pass1o Montani et Luc11 3, Bueno 804 /tzum. własne/: "Juz praw10 rozpalony ogień na spalenie naszyoh olał został ugaszony 1 zar płonqcego stosu został uśmierzony rosa Pańską. Zaś rozgniewany prezes kazał zamknąó męozenników w więziendu".

Passio SS.Saturnind et Dativ1 3, Bueno 974. 
continendos homines, non ad puntendos/25. Pobyt w węzientu trwał ponadto przez cazy czas przeprowadzania śledztwa, a więc względnie niedługo; tak przynajmniej postąpowano z męczennikarí w ciagu dwóch piermszych wieków. Gdy jednak w w. III 1 na poczłtku IV prześladowante chrześcijan nabrało charaikeru powszechnego, wierni pozostaพal1 więzieniach całe miesiace, ponlewaz wre wchodziło nie ty1e ukaranie rzekomej zbrodni, lle zinuszenie do aktu wyrzeczenta

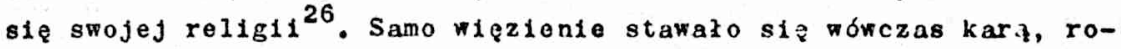
dzajem tortury. Nie było to jednak zgodne z prawen.

Cierpienia chrześcljan zalezaly nie tylko od oblektywnych warunków panujących w węzlentu, lecz taḱze od sytuacj1 1 subiektywnych odczuć zamknietych tam wyznawców Chrystusa. Tak np. w słowach \$w. Perpetul, opisującej swóf pobyt więzieniu moźna wyczuć wstręt 1 niesmak osoby przyzwyczajonej do wygód 27 . Aresztowant bardzlej zaprawient w trudach 1 wytrwalsi szybciej przyzwycajal 1 sie do warunków więziennych 1 łatwiej znosili plerwszz próbę, np. Lucjusz, Montanus $1 \mathrm{ch}$ towarzysze aresztowant za cesarza taleriana ${ }^{28}$. Jednak zarówno dla pierwszych, jak 1 drugich warunk 1 te do tego stopnia byky cizzkio, ze nawet wspomniani Lucjusz 1 jego towarzysze, mów1l1 o pobycie więzieniu z przerażeniem ${ }^{29}$. Wiele téz oczywiscle zalezało od rodzaju więzienia. Najciezszymi były tzw. Wiegie-

25 Digesta XLVIII, t1t. XIX 8. Por. P.Allard, o męceństwie, Warszawa 1914, 158 n; B.Lesińsk1, Wz. Rozwadowsk1, Historia prawa, Warszawa-Poznań $1980,199$.

26 Por. Lactatius, Divinae Institutiones V 30, PL 6, 438; Passio Montani et Lucii 12, Bueno 811.

27 Passio SS.Perpetuae et Felicitatis 3, Bueno 422, Nomaniewska 388: "Przerazenie mnie ogarnęło, gdyz nigly przedtem nie znajdowałam sie w takich clemnościach. Ach, dzień to by straszny. Upaz nie do zniesienia wskutek natłoku ludzi, zniewagi ze strony żołnierzy". Por. tez Tertulianus, Ad martyres 2, CC 1,4, PSP 5,32: "Jesteście w ciennościach... kajdanach... nie ma tam czym oddychać".

28 Passio Montant et Luc11 3, Bueno $804 / t ł u m$. wasne/: "K1edy zostaliśmy zaprowadzent do więzienia przez zołnierzy nie przestraszyliśmy sie strasznej ciemności tego miejscan.

29 'Pamze, "Spędzonych tam dni 1 przeżytych nocy nie mozra wyrazić słowami. Męczarnie wiezienia nie dadza się ujać w zadne określenie. 
nia podzleme /imi carceres/30. W takim waśnie podziemnym lochu przebywał przez 16 dni zatrzymany w $303 \mathrm{r}$. blizej niezidentylikowany biskup Feliks 31 .

oprócz stałych niewygód riezzienia stosomano dodatkowe środki dręczenia chrześcijan jak: zańcuchy /ferrum-vincula/, dyby/poona nervi/, gród 1 pragnienie. O zańcuchach móxi więsszość teistón źródłowych. 0 nich, jako narzędziu przynoszacym palmę zmycięstra ตspominaja wyraźnie z uniesionien zatrzyman1 $258 \mathrm{r}$. Monatanus 1 Lucjusz ${ }^{32}$, nieświadomi, że czeka lch jeszcze kara głodu 1 pragnien1a33. F gorącym klimacie afrykańskim szczególnie uciazliwa kara by 1 brak świezej wod.y, powodujący przypadkl zachorowaí, a nawet smlerc1 ${ }^{34}$. Mimo pragnienia 1 glodu, którego dośxiadczall jednakomo mszyscy skazaircy, zdarzały sie rypadk1, ze męczennicy oddawall dla słabszych od siebie suój bardzo skromny pokarm ${ }^{35}$. Kara "nervus" po-

30 Por. Prudentius, Per1stephanon V 241-257, CC 126, 302-303: "TT najnizszej czesci mijzienia znajduje sie miejsce czarniejsze od samych clemności, zamkntęte glazami niskiogo sklepienia. Panuje tam wieczna noc, której nigdy nle odwledza griazda dzienna; jest to istno piekzon.

31 Passio s.Felici 5, Bueno 962: por. A.Bober, Antologia patrystyozna, Kraków 1965, 99.

32 Passio Nontani et Luc11 6. Bueno $806 / t z u m$. Nlasne/: Mo dniu radosny 1 chwaso kajdi 1 ! 0 milsze od mszystkich pragnién zańcuchy. O zelazo zaszczy iniejsze 1 drozsze od najlepszego złotal o z griycie tego zelaza, który rozlegaz sie przy przesuranius po innye zelazie".

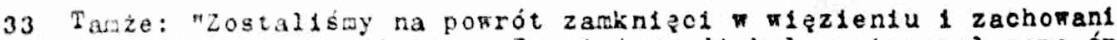
do nastepneso zwyclęstra. Zrycięzony diabel zastosowal nowe środki; postanowil dosuladezyć nas glodem 1 pragnieniem 1 proradzll té strasznil $809,811-813$.

34 Tanze 6,7,3, Bueno 805-807, 808-509; F roku 250 perien Lucjan zharca pisal do siego przyjaciela Rzyme /Cyprianus, Epistola $22,2, P L 4,254, P S P$ 1,79/: "Na rozkaz cesarza mielismy być glodem 1 pragnieniem nẹkan1, a bylismy zamkięci dwóch konorach. Dobrze znosiliswy gíd 1 pragnienie. Natomiast zaduch z porodu thoku byz tak nieznosny, ze nikt nle mógz nytrzymać". Dalej nymienia męczemikók, którzy zginzli kanieniolomach, na torturach, na sledztrie $i$ wizieniach $z$ glodu. Tych ostatnich bylo najuięcej bo az 13 os ́́b. Sam tez przebyra nizzieniu 1 jak p1sze: "Otrzymalising troche cilloba 1 oumierzona 1 ośc wody na 5 dus".

35 Tak wasinie uczyniz Plarian zamknięty w więzientu ze wspominanymi ryzej męczennjkani: Passto Montan11 et Luc11 21, Bueno 819. 
legała na tym, ze rozwarte przy pouocy skórzanych rzemient /nervus - stąd nazwa/ nogi więźniów, leżłcych na plecach, wkładano do otworów zrobionych $\mathbf{w} k$ kodzle drzewa. Otwory te były często tak bardzo oddalone od slebie, ze sprawiały ogromny ból skazanicowi ${ }^{36}$. Karze takiej poddawane były nawet kobiety 37 .

Chrześcijanie przebywajacy w wezlentach nie byli zupelnie od1zolowant od swiata zewnętrznego. Wiqkszość z ntch utrzymywara kaczność ze współwyznawcami na wolnośc1, którzy dostarczali tm róznorodnej pomocy. Wiemy np., ze diakont Tercjusz 1 Pompontusz przekup111 strazn1ków ${ }^{38}$, dzięki czemu Perpetua z resztą towarzyszy dostała wygodniejsze miejsce w wiezientu, a nawot pozwolono jej mieć przy sobie jej własne dziecko39. Hówniez po wyroku, gdy przeprowadzano 1ch do więzienia obozowego / in carcerem castrensem/, skąd mieli być wydani na rozszarpanie przez dzikie zwlerzęta, mogli kontaktować sle z braćm1 na wolnośc1. Perpetua napłsaławówczas: "Bracia c1 umacnia11 nas wierze 1 my nawzajem pocieszallśmy slę 1 podnosili na duchu $^{40}$. Pomoc taka organtzował zarówno Kościół, Jak 1 rodziny uwięzionych. Wyraził to Tertulian w słowach: "Wszystko, co jest konieczne dla clała, dostarcza Kościól 1 wajemna miłość braterska"41. Jak dalece było to rozpowszechntone, śladczy fakt, 1z św. Cyprian radził wiexnym w czasie przé́ladowanta Decjusza, by nie chodzili do wiezienia w zbyt wielkiej liczbie. Mogłoby to bowiem wabudzić podejrzenta 1 rozdraznic straże oraz spowodowac całkowity zakaz odwio$\operatorname{dz} 1 \mathrm{n}^{42}$.

Kośc16x jednak dostarczał nie tylko pomocy doczesnej, lecz takzo duchowej. Wlemy, ż juz przed Cyprianem niektórzy biskupi war-

36 Por. Tertullianus, Ad martyres 2,4, CC 1,4: "Nihil crus sentit in nervo, cum animus in coelo est":

37 Pass1o Perpetuae et Felicitatis 8, Bueno 427: "Dio quo in nervo mansimus" - Domaniewska 392: "W dniu, w ḱorym akrepowano nas 1 przykuto do miejsca".

38 Tamze, 3, Bueno 422.

39 Tamze.

40 Tainze VI; VII /Bueno $425 \mathrm{nn}$; RH 2/3, 392.

41 Tertullianus Ad martyres 2,4, CC 1,4, PSP 5,34 .

42 Cyprianus Epistola 5,2, PL 4,231, PSP 1,38 . 
taginie nieli zwyczaj posyłania do więzień diakonów, by czytali męczennikom Pismo św. ${ }^{43} \mathrm{Za}$ czasów Cypriana udawali sié tam kapłani 1 diakont w pewnych odstępach czasu, aby "sprawować oflare u wyznawców"44. W "Pasj1 swi żtych Montanusa 1 Lucjusza" czytamy, ze jednemu z nich wiezientu ukazał się wo śnie młodzlentec, który przyniósł czary z inlekiem 1 zapowiedział dostarczenie dalszych. Następnego dnia faiktycznie przyniesiono męczennikom pokarm 1 Komunie ów. /alimentum indeficiens/ 45 . N1e wchodzac blizej w problem autentyczności tej wizjl należy podkreśl1ć, ze jest ona m.in. wyrazem tęsknoty uwiezionych za Eucharystia. Innym sposobem podtrzymywania na duchu przebywajłcych więzleniu chrześcijan było wysyłante 1m Iistón, a nlekledy nawet całych traktatów o męczeństwio. Chociaz w omawianych tutaf Aktach 1 Pasjach nie ma o tym wzmlank1, w literaturze tantego okresu istnieje wiele na to dowodów. Wiadomo, ze Tertulian jedno z pierwszych swojch pism skierowal właśnte do męczenników z zacheta do wytrwania 1 odwag ${ }^{46}$. Podobnie św. Cyprian jest autorem nyboru tekstów biblijnych, sporządzonego w celu umocnienia $w$ wierze 1 podtrzymania na duchu uwięzionych ${ }^{47}$. To samo przeznaczente miał szereg jego zachowanych 1 istów ${ }^{48}$.

Z powyzszych uwag wynika, ze warunk1 wiezienne przyszłych meczenników były w pewnym sensie specyficzne 1 rózniły sie dość 1stotnie od sposobu traktowania innych więzinió. Trzeba tu przede wszystkin poukroślić niezgodność traktowania chrześcijan z prawem rzymskim, nie znającym wigzienta jako kary samoistnej. W odniesieniu do chrześcijan przekraczano przepisy prawne, przetrzymujac loh nawet latami, by złanać ich ducha. Wigzienie więc było nie tyle środkiem prewencyjnym, ile raczej środkiem perswazj1 1 przynusu fizycznego. Inna specyficzniz cochy pobytu chrześcijan w wezieniach było wymie-

43 Tenże: Spistola 15,1, PL 4,254, PSP 1,64.

44 Tenze: ipistola 5,2, PL 4,231, PSP 1,38 .

45 Passio Montani et Lucii 9, Bueno 809 .

46 Por. Ad martyres, CC 1,1-8, PSP 5,31-39.

47 Por. Ad Fortunatum de exhortatione martyr11, PL 4,651-676.

48 Por. Epistolae: $6,10,12,76,77,80,81$, oraz 11 sty skierowane do Cypriana, tamze $7 \dot{8}, 79$. 
rzanie kar dodatkowych, taktch jak: pozbawiente pozywienia 1 wody, zakuwanie w dyby itp. Dotkliwość kar wįziennych była łagodzona przede wszystkim przez odwiedziny oraz wsparcie duchowe 1 materialne współwyznawców. Niejednokrotnte warunks pobytu zależały od obsługi rięziennej. Jedni dozorcy 1 strażnicy z sympatil dla chrześc1jan, Inni zaś przekupleni staralı się ulzyć ưlęzionym. Ostatecznie Jednak istotnym elementom pobytu chrześcijan w wiezieniu było przygotorante sie na śmierć, a tym samym złożenie śwladectra Chrystusowi uznavanemu za Pana ich zycia.

\section{Przejary życia religijnego}

Nasuwa sie wreszc1e pytanie, waki sposób na dotychczasowym etapie postępowanta karnego ujawniała się wiara uwiezionych chrześcijan. Otóz trzeba zaznaczyć, ze 1ch zewnętrzne zycie religijne wyrazało sie przede wszystkim wodlitwie, przyjmowaniu Eucharyst11 oraz wizjach 1 objawientach.

Modlitwa była dla uwięzionych wyznawców Chrystusa źródłom wiary 1 nadziei, a momentach najtrudnjejszych szczcóólnyin pokrzepien1em. Np. Montanus, Lucjusz 1 lch towarzysze, zagrożcni śmlercia przez spalente zywcem, zaczell sie modlié. Niemozliwość rozpalenta przez prześladowców przygotowanego stosu, była - według autora pasj1 - wynlkiem modlitwy. Swladcza o tym słowa w ustach męczenników: "Leząc powtarzaliśmy modli.twy z cała wiarą $i$ zaraz otrzynaliśmy to, - co prosiliśmy"49. W świetle tego oplsu w1dad wyraźnie, ze meczennicy nie traktowall modlitwy jedynie jako zwykzego aktu wiary, leoz głęboko byli przekonani o jej skutecznośc1, przyrómnujac swoja sytuacje do zdarzeń biblijnych. Swiadectwem tego przy oplsie męczeństwa Montanusa 1 towarzyszy jest odwołanie sie do przykładu trzech młodzleńców, poddanych próbie ognia $/$ Dn $3,19-24 / 50$, którzy podobnie

49 Passio Montani et Lucil 3, Bueno 804.

50 Tamze: "Nietrudno było nam, w1erzącym, rzeczy nowe odnosic do starych przykładów, kledy Pan objawiał swa moc przez Ducha, gdyż Ten, który okazał swa łaske trzem młodzieńcom, zwycięzyz
także 1 w nas". 
nie przestraszyli się okropnych warunków panujacych w więzientu ${ }^{51}$. Modlitwa męczennikón była nie tylko modlitwa prośbydo Boga o ratunek. Przy lekturze dokumentów o męczeństwie zaskakuje nas fakt, ze w tak trudnych sytuacjach zyclowych stać było męczenników równiez na modlitwę uwieluienia Boga 1 dzięczyntenta Mu za okazje do męczeństwa, traktowana jako znak szczególnej kask1. Modlitwa uwielbienta 1 dzlökczyntenia, nie należca do rzadkośc1 w oplsach męczeńskich, wskazuje, iz tego rodzaju postawy nie nalezały do wyjątków. Lystarczy tu przytoczyé opis męczeństwa lektora Mariana mraz z towarzyszam1 z $258 \mathrm{r}$., istórzy po sroglch przesłuchaniach modlill sle w drodze powrotnej do wiezienia, Nysławiajzc Boga, co autor Pasji wyraził słowam1: "/Marlan/ wielce uradowany swolm triumfem powrócil do wiszienta. Tain $z$ Jaíubem 1 pozostałymi braćm1 wysławial cz̧̧stá modlitwa radość Pańskiega zwyclesstwan ${ }^{52}$. Podobnte mimo grozy sytuacjt 1 niepewności jutra zachowyali sig chrześcijanie aresztowant w Abttyufe. Prowadzeni przez zołnierzy do Kartaginy na przesłuchanie przez calt droge byll ralośni 1 wesell do tego stopria, że śplowali "hymny 1 pieśni pochwalne na cześć Pana"53.

Męczennicy modlili siz również za innych. Nawet w bardzo trudnych okolicznościach zyclowych paintętall o nspółbraciach w wierze 1 za wzorem Chrystusa oflarowywall za nich swoje clerplenta dajac wyraz niezwykle głęboklej postary chrześc1jańskiej. Przykładem moze tu być św. Perpetua, modlazca się wiezzientu za Dinokratesa, swego zmarłego, siedmioletniego brata ${ }^{54}$.

Alsta 1 pasje męczéíske stosunkowo rzadko daja opis samego momentu aresztowania 1 pobytu męczenników $w$ węzientu, a jeszcze

51 Tainże, 4, Bueno 804.

52 Passio Mariani et Jacob1 5, Bueno 829, tłum. waasne.

53 Passio SS.Saturnini et Dativi 4, Bueno 974.

54 Passio S.S.Perpetuae et Felicitatis 7, Bueno 426-427, Domaniewska 391-392: "Gdy wszyscy modilliśmy Gie, nagle w nodlitwie nieumyślnio wyisówiłam imie Dinokratesa. Ogarnęzo mnie zdumienie, gdyz dotychozas nie myślałam o nim woale; teraz zaś, gdy przypomntałam sobie smutnz jego dole, zaplakałam nad nim. I natychmiast zrozumiałam, ze obowiłzkiem molm jest modlió sie za niego, 1 ze jestem tego gouna. I zaczezzen modilo sie bardzo goraco 1 błagać Pana... Modliłen sie za niego nieustannie dniami 1 nocaml, z płaczen 1 jękiem biagająo o jego zbawienie". 
rzadziej modiltwy w tych okolioznościach. N10 mozna Jednak z tego wyolagac wnlosku, 12 modl111 sig onl mazo lub wcale. Byé moze dla autorów Pasjl byzy to fakty tak oozywiste, 1z pomijall je milczeniem uwypuklając raczes wydarzenta bardziej niecodzienne ${ }^{55}$.

Mazo równiez miejsca pośmięcaja opisy męczeństw przyjmowantu Komunil św. przez ư1ęz1onych. Wladomo, zo Kośolól jako rspólnota otaczaz opleka swo1ch uwiezionych wspóxwyznawoów, zanoszzo im Eucharyst1e przez kapłanów 1 diakonów ${ }^{56}$. Mozna tu wspomnieś niejakiego Emiliana, który przebymając więzienlu razem z Marlanem 1 Jakubem, nawet tam pomnazaz dobrowolnte swoje posty 1 często sie modliz oraz na przyszze zycie przygotowywaz sie - Jak pisał autor Pasj1 - karm140 B19 pokarmem 1 sakramentem Pańsk1m"57. Niektórzy przekładaja ten tekst, ze Emilian wiezieniu codziennie przyjmowal Eucharyst1e ${ }^{58}$. Moźna by więc sadzić, lz albo gmina chrześcijańska dostarczała zatrzymanym Komunit św., albo w węzlentu sprawowano Eucharystię. Potwierdzeniem drugiego przypuszczenia mógłby być dość częstý fakt obecności więzientu duchownych: S1skupów 1 kapłanów, którzy sprawowaliby Najślietsza 0eiare wiejscu odosobnienia. Jest to tylko hipoteza, poniewaz nasze źródła nic wprost o tyin nie mówia. Codzienne przyjmowanie Eucharyst11 przez Emlliana nie stanowi zadnego domodu, poniewaz wśród chrześcijan pojmanych razen z nim nie byto prezbiterów ani biskupów a tylko diakon Marian 1 lektor Jakub. Innym wyrazem zyola religijnego więzlonych chrześcijan były wizje 1 objamienta. Wplywaky one zasadniczo zarówno na 1 ch postawe, ukazująo sens clerpleń, Jak 1 na współczesnych chrześcijan na wolnośc1, Jako namacalny dow d oplek1 Boga nad spolm1 wyznawcami. Tuz po aresztomaniu 1 osadzentu $w$ wiezientu męczennicy bylı często zdezorien-

55 Por. A.Malinowgk1, Modlitwy mezcumikow, TST 8/1981/ 109.

56 Por. noty 44145 oraz artykuz: S.Longosz, Niektóre aspekty teolog11 męczeństwa w literaturze wczesnochrzescijańskiej, TST T/1979/

57 Passio Marian1 et Jacob1 8, Bueno 833: Continuatio in carcore gemina superpositione lelunils, et orationibus saepe repetitis, per quas
devota mens pasta in alium diem et sacramento Del parabatur.

58 Tak np. tzunaozy D.Ruiz Bueno 833 : plicaba sus ayunos y daba a la continua "En, la carcel mult1to, Junto con la divina Bucaristla continua oración, único alimenotron. 
towant, nie wiedzleli co lch czeka, 1 nierzadko saml prosill Boga, by objawil im przyszło losy. Np. "Pasja sw. Perpetul 1 Felicyty", mów1, ze uwiqzient po ruoditwie otrzymali w wizji odpowiedź, ze czeka ich męczeństwo ${ }^{59}$. Fizje miały swego rodzaju symbolike, bo odwołymały słę do pewnych znaków, które często były zapowiedzia męczeństwa 1 wlecznef nagrody. Tak np. wizj1 opisanej w "Pasj1 Mariana 1 Jakuba" do undęzionych przyszedz młodzientec, wręczyl im czerwone pasy 1 kazaz 1 ść za soba na znak, ze zostana umęczeni ${ }^{60}$.

Zapowiedzi poprzez wizje przyszłych wydarzeń dawały męcenn1-

59 Passio SS.Perpetuae et Fel1c1tat1s 4, Bueno 422-424, Doman1ewska 389-390: "Pewnego dnia brat mós powiedzlal do mnie: "Czelgodna slostro, jesteś juz w wielkiej zasce u Boga; mozesz więo prosié Go, aby ci przez widzenie objawiz, jaki los dla ciebie przeznaczys: tneczeristwo czy ocalente". A ja pamietajac, ze dane m1 było poufnte rozmawlać z Boglem 1 dośwladczyć wielu Jego dobrodziejstw, oblecalam śwlecle menu bratu, zo spełnię jego zyczenle 1 rzekłam: "Jutro c1 odpowiem". I prosiłam 1 zostało mi objawlone. Zobaczyłarn we śnie złoti drabinę takiej wysokosc1, ze sięraza do nleba, ale tak waska, ze tylko po jednemu mozna było na nia wstepowac. Po obu stronach drabiny umieszczone były wszelklego rodizaju mlecze, dzidy, haki, noze; tak, ze jezeliby ktos wchodziz nieuwaznie, nie patrzizc wóre, clało jego zostałoby poszarpane 1 utkwiloby na owyoh narzędziach śmierci. A u stóp samej lrabiny lezał smok olbrzymi, który czatowaz na zblizajicych sie, powstrzyrajizc loh od wchodzenla. Saturus jednak zacził wchodzić 1 poszedz pierwszy;/nie by on ujety wraz $z$ nami $i$ púznicj dobrowolnte dat sie uwiezic, chcąo podzielić nasz los/. I doszedr do szczytu drabiny, 1 zwróciz sie do mnio 1 rzels: "Perpetuo, czekal na ciebie, ale uważaj, aby ten suok na clebie nie napaly". A ja powiedziazam: "Nic m1 nie zrob1, gdy oddam się pod opielie jezusa Chrystusa". A smok, jak gdyby sie mnie obawiał, spod sanej drabiny powoli podniósz głowe. Ja zaś, robizc plerwszy krok, na te głowe właśnie wstaptzan. I vieszzam 1 zobaczyłam olbrzymi ogród, a pośrodku ogrodu siedział siwy człowiek ogromnego wzrostu; ubrany by w strój pasterza 1 doll owieczk1. Naokozo niego ujrzałam wielotysieczny tłum ludzi w białych szatach. Człowiek ten odwrócil głowe, zobaczył mnie 1 rzekł do mnle: "Badź pozdrowiona, moje dziecię". Zawołał mnie 1 dał mi trochę nleka, z tego, które wydo1ł; a ja przyjęam ze złozonym1 rękoria 1 spozyłam. A wszyscy stojqcy naokoło rzokl1: "Amen". A ja na dźwięk głosu obudzlłam sie, czująo w ustach słodk1 smak czegoś, co jadłam jeszcze. Natychmiast widzenie to opowiedziałam memu bratu 1 zrozumieliśmy, ze męczeristro jest blisk1e; 1 przestaliśmy juź zupełnie w zyciu ziemskim pokładać nadziejen".

60 Passio Marian1 et Jacob1 7, Bueno 831. 
kuw spokój, a nawet, co moze wydawać slę niekledy dziwne, radość. Poncjusz Diakon, autor "Vita S.Cypriant", przytacza relacje Cypriana - wizji na zesłaniu, ze ściety zostante nieczem. lelacje swoja kończy słowatil: "Lękałem s1e z porodu niepewnego tłumaczenia/tej wizj1/ tak, że szczątki bojaźni tłumiły radość bijaç w sercu"61. Podobnie przepełnlent byl1 radośc1.z uwiezient współcześnt św. Cyprianow1 towarzysze Montana 1 Lucjusz, na skutek wizj1 Renusa, w której poprzez symbol pleknego ogrodu otrzymał zapownienle, ze $1 \mathrm{ch}$ wsystk1ch czeka nagroda zycia wiecznego ${ }^{62}$.

Jest rzecza pewną, ze w czasie pobytu w wezieniu, zwłaszcza podczas jego dłuzszego trwania, mozliwe były duchowe zalamania. W1zje Jakby na nowo podrywały ohrześcijan do wytrwania begdac jednocześnle swladootwem opleki Bozej w clęźkloj próble. Podkreśla to autor opisu męczeństwa Nariana 1 Jakuba w słowach: "Dla wierzących w Boga, zadne brudne miejsca, zaden czas nie jest smutny. Krzepi 1ch, poświeconych Bogu 0jcu, dniami 1 nocaun braterstwo Chrystusa. Bowlem Marianowi po torturach cielesnych objawiła sie w glębokim śnie Bota laska, by zawierzyz nadziei zbawienta"63. Oplsuje przy tym widzenie Mariana, który przed trybunałem nlebleskim zostaje przyjęty przez umęczonego wczé́ntej Cypriana 1 otrzymuje od niego wode do plcia ze źródła bijacego pośrodku ogrodu. Ogród 1 źródło miały oznaczać stan szczę́fliwośs 64. Analogiczny przypadek podtrzymywania wyznawcow na duchu notuje "Pasja Montanusa 1 Lucjusza", opow 1 adajaca Jak sam Chrystus, objawiajac sie swym wyznawcom, umacnia $1 \mathrm{ch}$ w wierze, wzyma do wytrwanta oraz wspiera swa kaska na drodze do meczeŕstwa. Trzeba tu równtez zaznaczyé, ze powyzsze wizje maja charakter chryotocentryozny, unaoczniajacy, jak bardzo chrześc1jante tamtych czasón wiazali swoje męczeństwo z mękł 1 śmierola chrystusa. Podkreśla to powyzsza pasja słowaw1: "Ten, Który zecho1ai bý́my by 11 dośwladczani, sam sprawiaz, to mielismy pomoc tych dośriadczeniach.

61 V1ta Cypriani 12, Bueno 741, POK $19,68$.

62 Pass1o Montani1 ot Luc11 5 , Bueno 805.

63 Passio Marlani et Jacob1 6; Bueno 830. 
Objawione to bowiel zostalo prezbiterowi Wiktorow1, naszemu nspółbratu w mazelistwie, który poniósł śnteré zaraz po tej w1zjłn65. otóz Wiktor vcześniej zobaczył widzeniu młodzleńca, w którym rozpoznaz "Pana" zaperniaj,łcego: "Chos teraz jesteście zamknięc1, Juz nledzugo będziecio cierpioc, urajcie, ja jestem $z$ wanin ${ }^{66}$.

Innyw rodzajem byty wizje poprzedzajzce bezpośrednto wykonanie wyroku 1 majłce niejako za zadanie przygotować uwięzionych na sam moment śmlerci. I tak na przykład św. Perpetua miała przeddzień lgrzysk przedzlwny sen, widzzc " nim usługujłcego $1 \mathrm{~m}$ wcześntej dlakona pomponiusza, który zaproradził jif do amfiteatru, gdzie stoczyła nlezwykła walke z Eglpcjaninem 1 pokonała go. Podsumowała to potem is swo1n pamietniku: "Zbudzilam sle 1 zrozumiakam, ze będe walczyła nle z dzikimi ziplerzetami, lecz z szatanem. Ale riedziałam, ze czeka mnle zwycisstwo"67. Wielu tez Innych moczenników przebywajacych w wizzientu tuz przed egzekucja miało wizje, które najcześciej zapowiadały przyszłe zwyciestwo 1 osiggniecie korony chwaky. Takie wizje aleli in.in. saturus, unezczony razem zerpetuz 68 , oraz Montanus $^{69}$, Em1lianus ${ }^{70} 1$ Jakub. Ten ostatni ujrzał na uroczystej uczcie swego rspółwiçźnta, biskupa sgaplusza, kłóry kilka dni woześniej został urazczony, a takzo tałego chłopca, jednego z bliźniakón, którzy usługiwali za zycia blskupowi, a istórzy razem z matka odda11 zycle. Terize chzopiec skierowal do Jakuba - oczywiścia w widzeniu - nastepujace slowa: "Cieszcie sie 1 radujcie; jutro bowten 1 wy sami badziecie z num ucztowal1"71. Zapowiedz przyszłoj chwały przygotowanej dla meczeników bez włtplenia wpływala na ich postawe w monencie skxaliania świullectwa krwi. Oczywiście, nie moźna wnioskorać z tego, ze jedynie wizje 1 objawienta były przyczyna takiej, a nie innej postawy chrześcijan. U jej fundamentów lezała głęboka wiara 1 calkowite oddanie sie sprawow wyznawanej religil. Zreszta

65 Passio Montan1 et Lucil 7, Bueno 806.

66 Tamż.

67 Passio SS.Perpetuae et Felicitat1s 10, Bueno 428, Domaniewska 393.

68 Tanze, 11-13, Bueno 430-433, Domantewska 394-395.

69 Passio Montiant et Luci1 11, Bueno 810-811.

70 Passio Warian1 et Jacob1 8, Bueno 833-834.

71 Talize, 11, Bueno 836. 
wizje 1 objawienta były potwiexdzenien tej wiary i płyngzy z jej głębi, a jednocześnłe były znakiem enocjonalnego przezywanla więzi z Chrystusen ${ }^{72}$.

$\mathrm{Na}$ marginesie niniejszych rozwaźaí warto jeszcze odpowledzleć na pytanie, dotyczizce dzisiejszej oceny faktu wizjl 1 objawien ${ }^{73}$. Zjawlska te moga "prawdzle budić pewien sceptycyzm i nledowierzanie, ale czy podobnych uczuć nie budza niektedy ewangeliczne oplsy cudów? Dla niniejszych rozwazaxí wazne jest to, ze przykłady wizjl 1 objawień znajduja sie w autentycznych dokumentach z tantego okresu.

Onawianie zycia religijnego u wiezionych chrześcijan ograniczylisiny właścirie do trzech zasadniczych i najcześciej wspominanych przejawów: modlitwy, przyjmowania Eucharystil i przeźyć związanych z objawientam1. Nszystkle sa nie tylko wyrazes glabokiej wiary w Chrystusa, lecz takize poczucia Jego realnej obecnośct w wielkim dramacie źycia, w męczeńskiej drodze chrześoijan, którzy do kolica pozostal1 wierni swemu Panu.

Ks. Eugeniusz Verdziuk - Tarno:sród

\section{RÖIISCH-AFRICAS WÄLREND VERHAFTUNG UND G \\ /Zusammenfassung/}

Der Artikel stllzt slch auf Informationen aus den Afrikanlschen Akten und Martyrerpassionen und besteht aus vier Kapiteln. In 1. Kapitel "Romlsche lesetzgebung und Christenverfolgung" beintht sich der Autor neben einer kurzen Darlegung der leschichte der Verfolgungen aufzuzelgen, aufgrund welcher Gesetze die antiken Christen vorfolgt wurden /Beschuldigung des Sakrilegs, der Majestutsbeleidigung, der Magie sowie unerlaubter Zusammenkunfte/. Im 2. Kap1te1 "Umstände der Verhaftung der Christen" wird daran erinnert, wer die Verhaftung unmittelbar vollzog und wie sich die Christen dabel verhielten. Im 3 .

72 Tego rodzaju opls nie pretenduje do jednoznacznego określenta charakteru wizj1 1 objawień.

73 M.Lods /Confesseurs et martyrs, successeurs des prophètes dans 1 Eglise des trois premiers siécles, Neuchâtel-Paris 1958, 29 nn/ uwaza chrześcijan - męczonników za nastepców pruroków, a wizje 1 objawienla są jednym $z$ dowodów na potwierdzente tej tezy; por "Wordorf: Nadzieja męczennikóp chrześcijańskich, "Znak" 26/1974/ 1387-1402. 
Kapitel "Gefungnisbedingungen" bespricht der Autor die Bedingungen, unter denen sich die festgenominenen Christen befanden, und zwar in der sog. Vorbeugehaft, d.h. vom Moment der Verhaftung an, whrend der Verhore bis zur Urtellsverkthiung. Ausser den ublichen Unbequomlichkeiten des GefHngnislobens wie Hunger und Durst wurden die filletlinge auch gefoltert. Die iestgenomienen Christen erfuhren jedoch Fursorge und Unterstutzung von Selten der K1rchengemelnden, aus denen sie stammen. Im 4. Kapitel "Erscheinungsformen des religiosen Lebens" schliesslich beintht sich der Autor darzulegon, auf wolche Welse die festgenommenen Christen Im Geflungnis ihren Glauben kundtaten; dies geschah durch das Gebet, den Empfang der Bucharistie sowio durch emplangene Visionen und offenbarungen. 